\title{
IMPACT OF WEEDS ON PADDY BIOMASS IN UPLAND RAINFED AREAS OF TERAI REGION OF NEPAL
}

\author{
M.D. Bhatt, S.P. Singh ${ }^{1}$ and A. Tewari ${ }^{2}$ \\ Department of Botany, Siddhanath Science Campus, Mahendranagar, Nepal \\ Email: bhattmd@rediffmail.com \\ ${ }^{1}$ Department of Botany, Kumaun University, Nainital - 263 002, India \\ ${ }^{2}$ Department of Forestry, Kumaun University, Nainital - 263 002, India
}

\begin{abstract}
Field experiments were conducted to analyze impacts of weeds on biomass of two varieties of rainfed upland paddy (cv. Radha-4 and Neemai) during the kharif session of 2004-2005 in the Terai region of Nepal. Four experiments were conducted in randomized block design with three replications. A total of 55 weed species were identified with densities of 240 individual plants per sqm in Radha-4 and 236 individual plants per sqm in Neemai. The annual net primary productivity of paddy crop was maximum (2329.3 $\mathrm{g} \mathrm{m}^{-2} \mathrm{yr}^{-1}$ in Radha-4 and $2170.3 \mathrm{~g} \mathrm{~m}^{-2} \mathrm{yr}^{-1}$ in Neemai) in weed-free plots and lowest (1659.8 $\mathrm{g} \mathrm{m}^{-2} \mathrm{yr}^{-1}$ in Radha-4 and $1659.4 \mathrm{~g} \mathrm{~m}^{-2} \mathrm{yr}^{-1}$ in Neemai) in unweeded plots. Hand weeding was done twice at 25 and 50 days after broadcasting, and proved to be better than herbicides in the paddy biomass. The mean maximum biomass of paddy in weed-free plots was 2418.7 and $2270.3 \mathrm{~g} \mathrm{~m}^{-2}$ in Radha- 4 and Neemai. This biomass was similar to twice hand-weeded plots being $1 \%$ lower in both the varieties. Compared to weed-free plots the biomass reduction in Radha- 4 and Neemai in herbicides treated plots was lower by $1.4 \%$ in both the varieties. Compared to weed-free plots the biomass reduction in unweeded plots was recorded $29 \%$ lower in Radha- 4 and $23 \%$ in Neemai. The weed biomass was highest in unweeded plots $\left(516.4\right.$ and $\left.437.6 \mathrm{~g} \mathrm{~m}^{-2}\right)$ and lowest $(169.3$ and $\left.192.3 \mathrm{~g} \mathrm{~m}^{-2}\right)$ in twice hand-weeded plots. The net annual primary productivity of weeds was highest (437.9 $\mathrm{g} \mathrm{m}^{-2} \mathrm{yr}^{-1}$ in Radha-4 and $376.6 \mathrm{~g} \mathrm{~m}^{-2} \mathrm{yr}^{-1}$ in Neemai) in unweeded plots and lowest (119.7 $\mathrm{g} \mathrm{m}^{-2} \mathrm{yr}^{-1}$ in Radha-4 and $145.5 \mathrm{~g} \mathrm{~m}^{-2} \mathrm{yr}^{-1}$ in Neemai) in twice hand-weeded plots. The trend of grain yield in both the varieties were; weed-free plots $(\mathrm{TT})>$ twice hand-weeded plots $\left(\mathrm{T}_{1}\right)>$ chemical fertilizer and butachlor plots $\left(\mathrm{T}_{2}\right)>$ unweeded plots $\left(\mathrm{T}_{0}\right)$.
\end{abstract}

Key words: Paddy, weeds, upland, biomass, Terai.

\section{INTRODUCTION}

Approximately 2.32 million ha of land is cultivated in Nepal of which 1.7 million ha of agricultural land is rainfed. The rainfed paddy is the most important staple crop in Nepal but the productivity is affected due to climate, edaphic and economic factors in foothills of Nepal. In hills and mountains, agriculture is still practiced in its traditional style. The traditional way of agriculture as practiced by majority of farmers is supposed to be one of the important factors for the poor performance of the agriculture sector in the country.

Weed management is as old as agriculture itself. Weeds are those plants, which are harmful, interfere with the agricultural operations, increase labours, add input to the cultivation and reduce the crop yields (Sen,2000). Weed problem varies from one crop to another, from one season to other, from one farm to other and even one section of a farm to 
the other (Rao, 1983). Many weed species have almost identical growth and requirements as paddy. The practices that benefit rice also benefit weeds, while the practices that harm rice also harm weeds (De Datta and Baltazar 1996).

Weeds are major problems specially limiting the growth and yield in paddy cultivation. They usually emerge faster than the rice plant, absorb available water and nutrients earlier, establish their growth earlier and suppress crop growth. The problem of weeds in upland rainfed rice during kharif season is extremely severe and causes 45$85 \%$ reduction in yield (Moody, 1982).

The low production because of limited suitable area for cultivation is further affected by weeds, which abound along with paddy crops. There is a need to assess the loss in paddy crop production because of these unwanted, useless and persistent weed species. Further to restrict the loss in paddy biomass and develop reliable methods by which the poor farmers can control the most common and abundant weeds. Keeping this in view, the present study was made to examine the impact of weeds on paddy biomass and grain yield in rainfed paddy growing areas of Terai region of Nepal.

\section{MATERIALS AND METHODS}

The field experiments were conducted during the kharif seasons of 2004-2005 at farmers' agricultural field at Tilachaur in Mahendranagar $\left(28^{\circ} 32^{\prime} \mathrm{N}\right.$ latitudes, $80^{\circ} 33^{\prime} \mathrm{E}$ longitudes, and 300 $\mathrm{m}$ amsl). The soil was silty clay in texture with $\mathrm{pH}$ 6.5. Climate is humid tropical with three distinct seasons in a year, viz. monsoon, winter and summer. Total annual rainfall during the study period was $1642.8 \mathrm{~mm}$ of which $90 \%$ was recorded during the monsoon months of the year.

The experiment was laid out in randomized block design with three replicates of plots sized $5 \mathrm{~m}$ x $5 \mathrm{~m}$. The four treatments applied were: TT- weedfree, $\mathrm{T}_{0}$-unweeded, $\mathrm{T}_{1}$-manured plus twice handweeded on 25 and 50 days broadcasting, and $\mathrm{T}_{2}$ chemical fertilizer plus butachlor (1.5 $\left.\mathrm{kg} \mathrm{ha}^{-1}\right)$.
Rice seeds (viz. Radha-4 and Neemai) were sown on the basis of farmers' practices using a seed rate of $80 \mathrm{~kg} \mathrm{ha}^{-1}$ in the first week of June with the arrival of pre-monsoon. The pre-emergence herbicide treatment was applied at 3 days after sowing. A fertilizer dose of $\mathrm{N}, \mathrm{P}$ and $\mathrm{K}$ was applied@100:30:40 $\mathrm{kg} \mathrm{ha}^{-1}$ respectively in TT, $\mathrm{T}_{0}$ and $\mathrm{T}_{2}$ plots. Full dose of $\mathrm{P}$ and $\mathrm{K}$ and half of $\mathrm{N}$ were applied as the basal dose and remaining $N$ was top-dressed in two equal splits at tillering and panicle initiation stage. In $T_{\text {, treatments farmyard }}$ manure was applied (a) $15 \mathrm{t} \mathrm{ha}^{-1}$. Weed-free and unweeded treatments were kept for comparisons. The crop was harvested in the second week of October. For the estimation of weed and paddy biomass three quadrats $(30 \mathrm{~cm} \times 30 \mathrm{~cm})$ at 25 days interval were randomly sampled within treatments and the annual net production of weeds and paddy was calculated by summing positive increments on successive sampling dates during the study periods (Singh and Yadava, 1974). All the data were statistically anaiysed by using the standard method of analysis of variance at $\mathrm{P}=0.05 \%$ significance level.

\section{RESULTS}

Major weeds of paddy fields: On the basis of Importance Value Index (IVI) twelve major weeds in upland rainfed paddy were Ageratum conyzoides (13.0), Alternanthera sessilis (10.2), Cynodon dactylon (9.5), Cyperus iria (12.5), Echinochloa colona (10.2), Echinochloa crus-galli (10.1), Eclipta prostrata (9.7), Eleocharis atropurpurea (13.1), Fimbristylis miliacea (13.4), Ischaemum rugosum (10.2), Lindernia opositifolia (13.2) and Lindernia procumbens (10.8). Among these $E$. atropurpurea and $L$. procumbens were late emerging weeds. In the studied major weeds, the maximum IVI was contributed of $F$. miliacea (13.4) and minimum of $C$. dactylon (9.5).

Weed population: A total of 55 weed species were recorded in both the varieties in unweeded plots. The density of weeds was 240 ind. $\mathrm{m}^{-2}$ in 
Radha- 4 and 236 ind. $\mathrm{m}^{-2}$ in Neemai. The weed population in all the treatments remained lower than unweeded plots. However, the weed population drastically increased when paddy was not weeded out during early stage of growth period. Weeds were effectively controlled with the application of pre-emergence herbicide butachlor (1.5 $\mathrm{kg} \mathrm{ha}^{-1}$ ); however, this herbicide was found less effective in second flush and late emergence monocots and dicots weeds. Twice hand weeding at 25 and 50 days after broadcasted significantly controlled the weed population.

Weed biomass: Weed biomass was affected due to crop weed competition in both the cultivars of paddy. The maximum total biomass of major weed species was $516.4 \mathrm{~g} \mathrm{~m}^{-2}$ in Radha-4 and $437.6 \mathrm{~g} \mathrm{~m}^{-}$ ${ }^{2}$ in Neemai unweeded plots $\left(\mathrm{T}_{0}\right)$. The lowest major weeds total biomass was 169.3 and $192.3 \mathrm{~g} \mathrm{~m}^{-2}$ in the manured and twice hand-weeded plots $\left(T_{1}\right)$ of broadcasted paddy Radha-4 and Neemai, respectively. The butachlor plus chemical fertilizer applied plots $\left(\mathrm{T}_{2}\right)$ recorded 244.5 and $268.4 \mathrm{~g} \mathrm{~m}^{-2}$ of major weeds in Radha-4 and Neemai, respectively. The major weeds biomass reduction by $67.2 \%$ in Radha- 4 and $56.1 \%$ in Neemai in manured and twice hand-weeded plots and $52.7 \%$ in Radha-4 and $38: 7 \%$ in Neemai in chemical fertilizer plus butachlor used plots compared to unweeded plots. The biomass of major weed species significantly differed $(\mathrm{P}<0.001)$ from the unweeded plots in both the cultivars (Fig, 1).

The total net primary productivity of the major weeds was highest $437.9 \mathrm{~g} \mathrm{~m}^{-2} \mathrm{yr}^{-1}$ in Radha-4 and $376.6 \mathrm{~g} \mathrm{~m}^{-2} \mathrm{yr}^{-1}$ in Neemai in unweeded plots $\left(\mathrm{T}_{0}\right)$, and minimum in twice hand-weeded plots $\left(\mathrm{T}_{0}\right)$ being $119.7 \mathrm{~g} \mathrm{~m}^{-2} \mathrm{yr}^{-1}$ in Radha-4 and $145.5 \mathrm{~g} \mathrm{~m}^{-2}$ $\mathrm{yr}^{-1}$ in Neemai. The total net primary productivity reduction was $72.6 \%$ in Radha- 4 and $61.4 \%$ in Neemai in manured plus twice hand-weeded plots
$\left(\mathrm{T}_{1}\right)$ compared to unweeded plots. In chemical fertilizer plus butachlor used plots $\left(\mathrm{T}_{2}\right)$ the total net primary productivity was reduced by $50.1 \%$ in Radha- 4 and by $40.8 \%$ in Neemai compared to unweeded plots (Table 1).

Paddy crop biomass: The maximum biomass (aboveground and belowground) after sowing at harvest in both the paddy varieties in weed-free (TT) in upland broadcasted paddy, being $2418.7 \mathrm{~g}$ $\mathrm{m}^{-2}$ for Radha-4 and $2270.3 \mathrm{~g} \mathrm{~m}^{-2}$ in Neemai. The minimum total crop biomass for broadcasted paddy was 1716.1 and $1745.0 \mathrm{~g} \mathrm{~m}^{-2}$ in unweeded plots $\left(\mathrm{T}_{0}\right)$ of Radha-4 and Neemai, respectively. In twice hand-weeded plus manured plots $\left(\mathrm{T}_{1}\right)$ the paddy biomass was 2402.6 and $2246.8 \mathrm{~g} \mathrm{~m}^{-2}$ for Radha- 4 and Neemai, respectively. The butachlor plus chemical fertilizer applied plots $\left(\mathrm{T}_{2}\right)$ recorded 2384.9 and $2238.8 \mathrm{~g} \mathrm{~m}^{-2}$ for Radha-4 and Neemai, paddy verities respectively. The difference in crop biomass between unweeded and weed-free treatments was $29.1 \%$ for Radha- 4 and $23.1 \%$ for Neemai. In comparison to weed-free conditions the crop biomass in manured plus twice hand-weeded plots $\left(\mathrm{T}_{1}\right)$ was more or less similar and just $0.7 \%$ lower in Radha-4 and $1.0 \%$ in Neemai. The paddy crop biomass in unweeded plots was significantly different $(\mathrm{P}<0.001)$ from the weed-free plots in both the varieties (Fig. 2).

The total net primary productivity of broadcasted paddy was highest in weed-free (TT) plots being $2339.3 \mathrm{~g} \mathrm{~m}^{-2} \mathrm{yr}^{-1}$ for Radha-4 and $2170.3 \mathrm{~g} \mathrm{~m}^{-2} \mathrm{yr}^{-1}$ for Neemai, and minimum in unweeded plots $\left(\mathrm{T}_{0}\right)$ being $1649.8 \mathrm{~g} \mathrm{~m}^{-2} \mathrm{yr}^{-1}$ for Radha-4 and $1659.4 \mathrm{~g} \mathrm{~m}^{-2} \mathrm{yr}^{-1}$ for Neemai. The total net primary productivity reduced by $29.2 \%$ in Radha-4 and $23.5 \%$ in Neemai in unweeded plots compared to weed-free plots. The total net primary productivity was lower by $0.4 \%$ in Radha- 4 and 
$0.9 \%$ in Neemai in manured plus twice handweeded plots $\left(\mathrm{T}_{1}\right)$ and $1.0 \%$ in Radha- 4 and $1.1 \%$ in chemical fertilizer plus butachlor used plots $\left(\mathrm{T}_{2}\right)$ compared to weed-free plots (Table 1).

Grain yield: The maximum grain yield in Radha- 4 and Neemai was in weed-free (TT) plots 52.2 and $46.4 \mathrm{q} \mathrm{ha}^{-1}$ compared to 30.1 and $30.3 \mathrm{q} \mathrm{ha}^{-1}$ in unweeded plots $\left(\mathrm{T}_{0}\right)$, grain loss being $42.3 \%$ and $34.7 \%$ because of weeds in Radha- 4 and Neemai varieties, respectively. Compared to weed-free plots the grain yield was $9.6 \%$ and $2.2 \%$ lower in twice hand-weeded plots $\left(\mathrm{T}_{1}\right)$ and $12.1 \%$ and $4.1 \%$ in herbicide treated plots $\left(\mathrm{T}_{2}\right)$ in Radha-4 and Neemai. The effect of manual weeding and herbicidal treatment significantly $(\mathrm{P}<0.001)$ increased the grain yield compared to unweeded plots of both varieties.
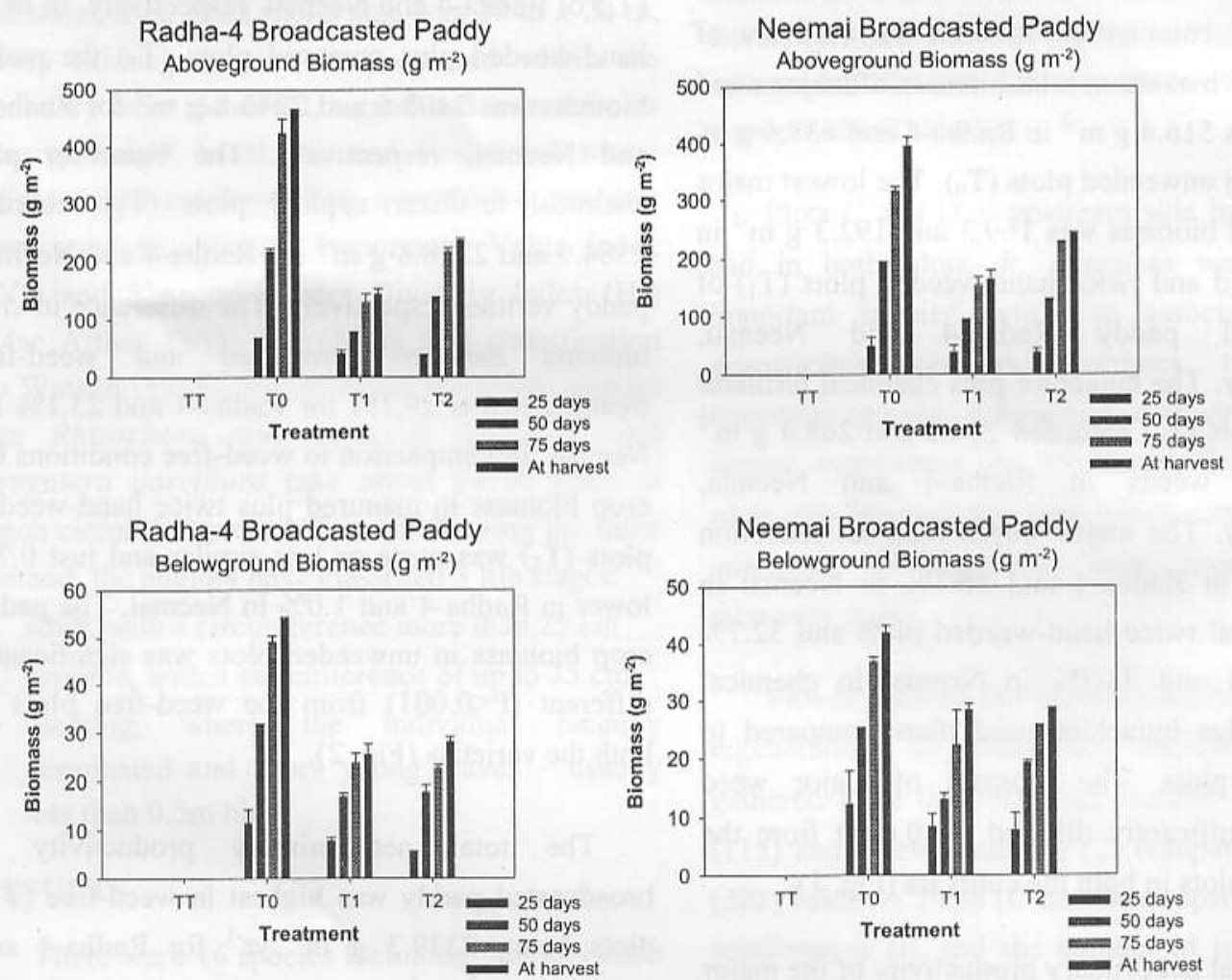

TT: Weed free; T0: Unweeded; T1: Manured plus twice handweeded; T2: Chemical fertilizer plus butachlor@1.5 kg/ha.

Fig. 1. Variation in aboveground and belowground biomass $\left(\mathrm{g} \mathrm{m}^{-2}\right)$ under different treatments of major weeds in broadcasted paddy crops Radha- 4 and Neemai. 


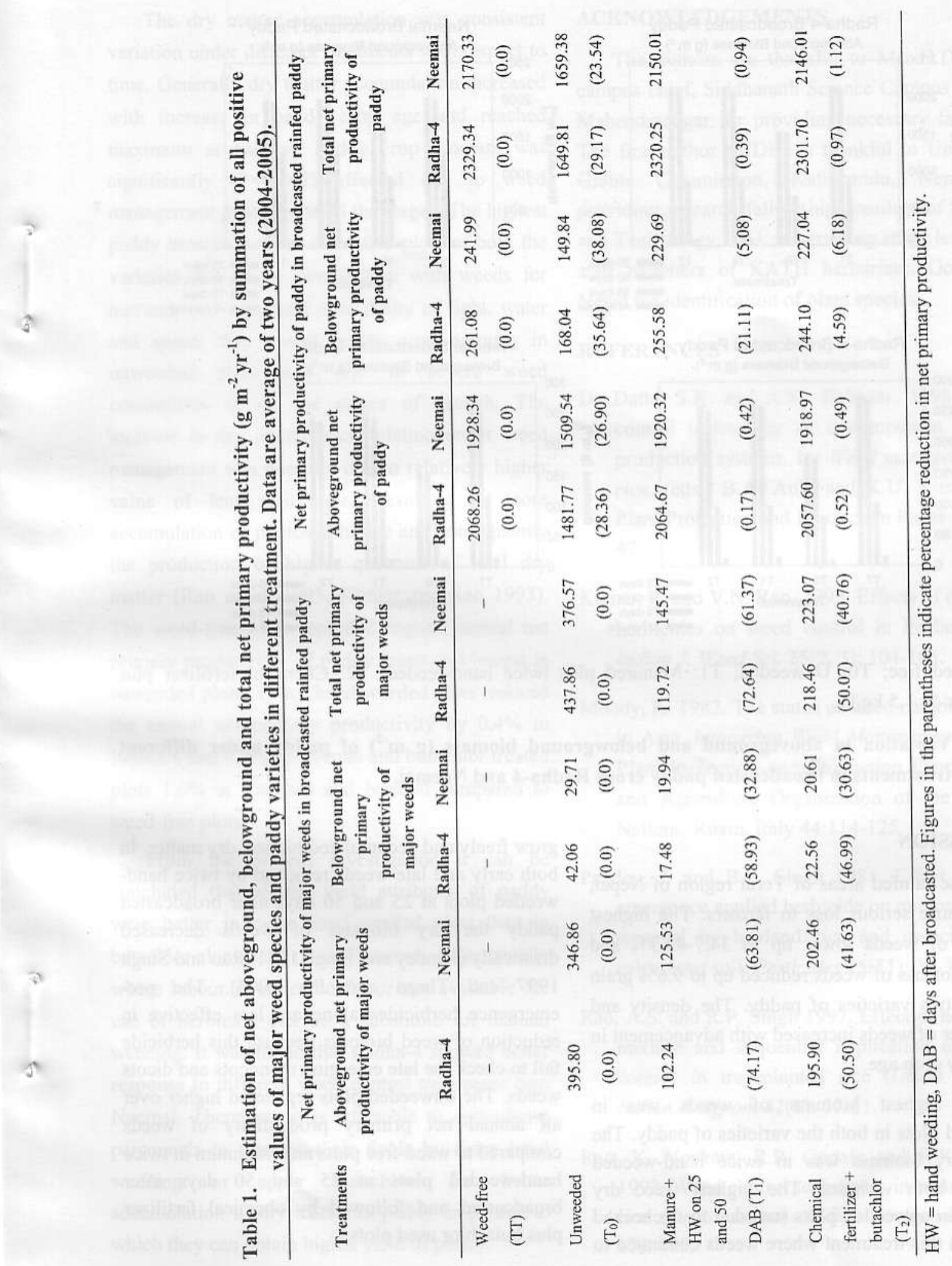

ECOPRINT VOL 13, 2006 

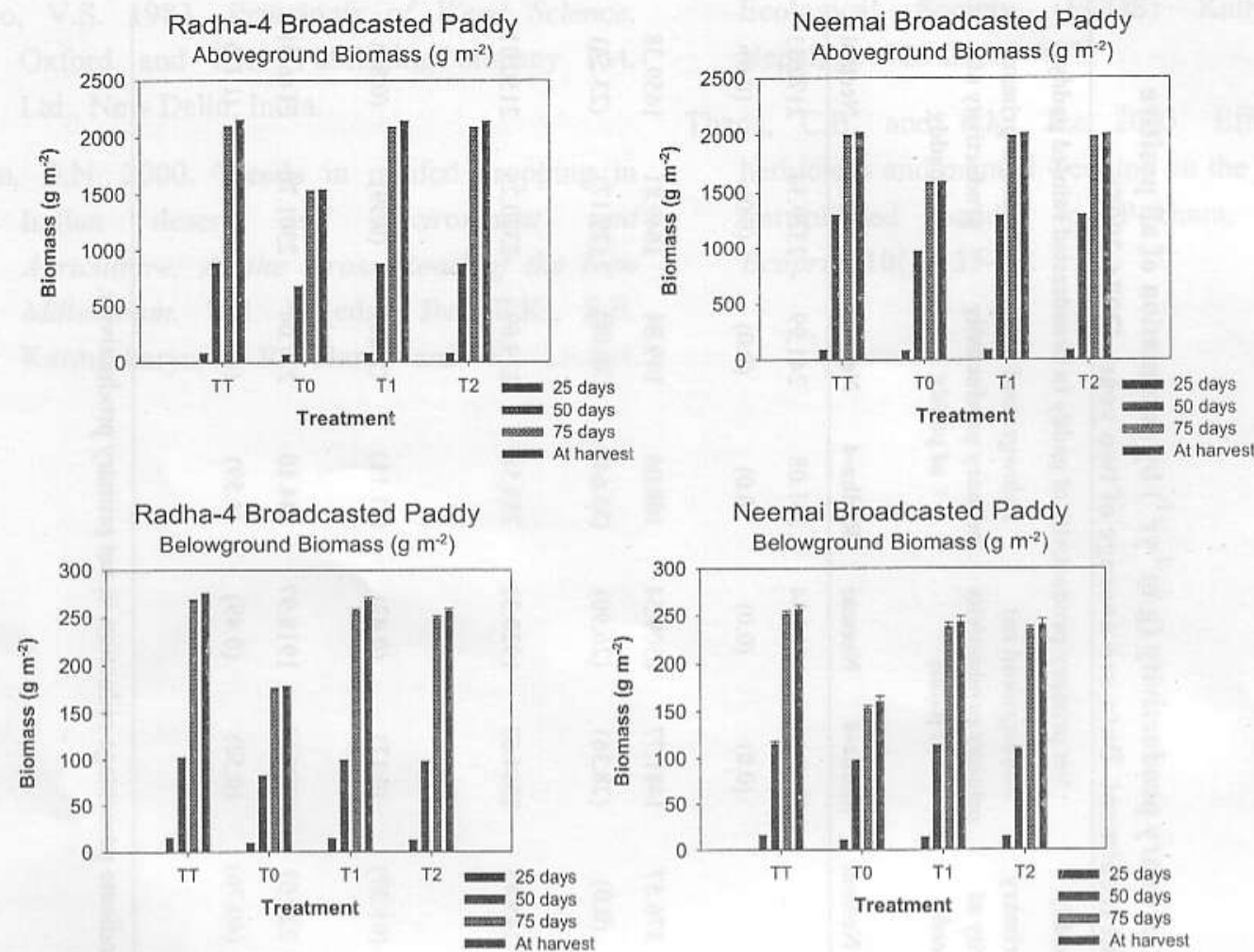

TT: Weed free; T0: Unweeded; T1: Manured plus twice handweeded; T2: Chemical fertilizer plus butachlor@1.5 kg/ha.

Fig. 2. Variation in aboveground and belowground biomass $\left(\mathrm{g} \mathrm{m}^{-2}\right)$ of paddy under different treatments in broadcasted paddy crops Radha-4 and Neemai.

\section{DISCUSSION}

In the rainfed areas of Terai region of Nepal, weeds cause serious loss to farmers. The highest biomass of weeds lower up to $34.7-42.3 \%$ and lowest biomass of weeds reduced up to $9.6 \%$ grain yield in two varieties of paddy. The density and dry matter of weeds increased with advancement in the paddy crop age.

The highest biomass of weeds was in unweeded plots in both the varieties of paddy. The lowest dry biomass was in twice hand-weeded plots in both varieties. The highest weed dry biomass in unweeded plots was due to unchecked growth in this treatment where weeds continued to grow freely and accumulated highest dry matter. In both early and late weeds removed by twice handweeded plots at 25 and 50 days after broadcasted paddy the dry biomass of weeds decreased drastically (Pandey and Singh 1981, Rao and Singh 1997 and Thapa and Jha 2003). The preemergence herbicides alone are less effective in reduction of weed biomass because this herbicide fail to check the late emerging monocots and dicots weeds. The unweeded plots registered higher over all annual net primary productivity of weeds compared to weed-free plots and minimum in twice hand-weeded plots at 25 and 50 days after broadcasted and followed by chemical fertilizer plus butachlor used plots. 
The dry matter accumulation was consistent variation under different treatments with respect to time. Generally dry matter accumulation increased with increase in paddy crop age and reached maximum at harvest. Paddy crop biomass was significantly $(\mathrm{P}<0.001)$ affected due to weed management practices at all the stages. The highest paddy biomass was in weed-free plots of both the varieties due to no competition with weeds for nutrient, and increased availability of light, water and space. The lowest paddy crop biomass in unweeded plots was due to severe weed competition in all the stages of growth. The increase in dry matter accumulation under weed management was possibly due to relatively higher value of leaf area index resulting in more accumulation of photosynthesize and consequently the production of higher quantum of total dry matter (Rao et al. 1993, Kumar and Rao 1993). The weed-free plots recorded highest annual net primary productivity of paddy crops and lowest in unweeded plots. Twice hand-weeded plots reduced the annual net primary productivity by $0.4 \%$ in Radha- 4 and $0.9 \%$ in Neemai and butachlor treated plots $1.0 \%$ in Radha- 4 and Neemai compared to weed-free plots.

From the present investigation it can be concluded that all the yield attributes of paddy were better in twice hand-weeded plots than in butachlor alone used plots. However, economically where labour is either costly or not available the use of herbicide can be a substitute for manual weeding. It was found that Radha-4 showed better response to different weed control treatments than Neemai. Therefore, it is advisable to agricultural personnels to manage their fields by twice hand weeding or apply butachlor, for better accumulation of dry matter in paddy crops due to which they can obtain higher yield of paddy.

\section{ACKNOWLEDGEMENTS}

The authors are thankful to Mr. D.D. Joshi campus chief, Siddhanath Science Campus (T.U.), Mahendranagar for providing necessary facilities. The first author (MDB) is thankful to University Grants Commission, Kathmandu, Nepal for providing research fellowship, Institute of Science and Technology, T.U. for granting study leave and staff members of KATH herbarium, Godawari, Nepal for identification of plant species.

\section{REFERENCES}

De Datta, S.K. and A.M. Baltazar. 1996. Weed control technology as a component of rice production systems. In: Weed management in rice. (eds.) B.A. Auld and K.U. Kim. FAO, Plant Protection and Production Paper 139:2547.

Kumar, P. and V.N. Rao. 1993. Effects of different herbicides on weed control in lowland rice. Indian J. Weed Sci. 25(2, 3): 104-105.

Moody, K. 1982. The status of weed control in rice in Asia. Improving Weed Management. FAO, Plant Protection and Production Paper. Food and Agriculture Organization of the United Nations, Roam, Italy 44:114-125.

Pandey, J. and B.P. Singh 1981. Effect of preemergence applied herbicide on micronutrients removal by lowland rice and associated in calcareous soil. Pesticides 15(11): 32-34.

Rao, A.S. and R.P. Singh 1997. Effect of herbicide mixture and sequential application on weed control in transplanted rice (Oryza sativa). Indian J. Agron. 42(1): 77-81.

Rao, K. Venkata, R.P. Gopala and R.K. Rama 1993. Weed control techniques in transplanted rice (Oryza sativa). Indian J. Agron. 38(3): 474-475. 
Rao, V.S. 1983. Principals of Weed Science. Oxford and IBH PublishingCompany Pvt. Ltd., New Delhi, India.

Sen, D.N. 2000. Weeds in rainfed cropping in Indian desert. In: Environment and Agriculture; At the Cross Road of the New Millennium. Vol. 1 (eds.) Jha, P.K., S.B. Karmacharya, S.R. Baral and P. Lacoul.
Ecological Society (ECOS) Kathmandu, Nepal, pp. 223-228.

Thapa, C.B. and P.K. Jha 2003. Effects of herbicides and manual weeding on the yield of transplanted paddy in Pokhara, Nepal. Ecoprint 10(1): 35-41. 